\title{
LA CALIFICACION DEL CONCURSO EN LA NUEVA LEY
}

\author{
Fernando Gómez Martín \\ Profesor Asociado de Derecho concursal \\ Universidad de Deusto. Bilbao
}

Sumario: 1. Derecho concursal mercantil vigente. 2. En el nuevo concurso. 2.1. Fortuito. 2.2. Culpable. 2.2.1. Supuestos de culpabilidad. 2.2.2. Presunciones. 2.3. Cómplices. 2.3.1. Derecho concursal vigente. 2.3.2. En el nuevo concurso. 2.4. Informe. 2.5. Tramitación de la sección de calificación. 2.5.1. Sentencia de calificación. 2.5.2. Sustitución de los inhabilitados. 3. Recapitulación.

En reciente colaboración, sobre las funciones más relevantes de los administradores concursales, anunciaba volver sobre la calificación del concurso, pieza decisiva, si procede su formación, en la que se evaluará la conducta del deudor, en los dos años anteriores a la declaración judicial y con posterioridad, es decir, durante la tramitación del procedimiento.

Cuando tenga lugar la aprobación judicial de un convenio concursal, en el que se establezca, para todos los acreedores o para los de una o varias clases, una quita superior a un tercio del importe de sus créditos o una espera superior a tres años, y en todos los supuestos de apertura de la fase de liquidación, el concurso de acreedores se calificará como fortuito o como culpable, en la sección sexta del procedimiento, según dispone el art. 164.

En la exposición de motivos de la Ley concursal ${ }^{1}$ se afirma: «Una de las materias en las que la reforma ha sido más profunda es la de calificación del concurso».

\section{Derecho concursal mercantil vigente}

La suspensión de pagos puede ser objeto de calificación, cuando es declarada la insolvencia definitiva, según dispone el art. 20 de la Ley especial, con remisión a los arts. 886 a 894 del Código de Comercio,

${ }^{1}$ Ley 22/2003, de 9 de julio, Concursal (BOE núm. 164, 10 julio 2003), en vigor desde el 1 de septiembre de 2004 . 
salvo que se sobresea el expediente, aunque compatible con la aprobación de convenio, de acuerdo con la Circular 1/95, de 6 de abril, de la Fiscalía General del Estado, que concreta en la siguiente conclusión: " $4{ }^{a}{ }^{a}$... posición del Ministerio Fiscal sobre la continuación o no de la pieza de calificación abierta: a) Si tras haberse iniciado la tramitación de la pieza para exigir responsabilidades, el otro procedimiento, el de suspensión de pagos, se sobreseyere por alguna de las causas legales, tal conclusión extiende sus efectos extintivos a la pieza separada, por lo que cuando el Ministerio Fiscal conociere que el expediente de suspensión de pagos ha sido sobreseído, dictaminará en la pieza en el sentido de que procede tenerla por concluida, absteniéndose de formular demanda, y si el sobreseimiento se produjere en tramitación ya el juicio de responsabilidad, desistirá de él; b) Si al auto que declara la insolvencia definitiva sigue... la aprobación del convenio, esta situación es compatible con la prosecución de la pieza y con la calificación de culpable o fraudulenta para la suspensión de pagos, así como con la formulación de demanda por el Ministerio Fiscal».

El Tribunal Supremo ha declarado que la aprobación e incluso el cumplimiento del convenio, en la suspensión de pagos, no es incompatible con la pieza de calificación y la consiguiente demanda de responsabilidad (Sentencias de fechas 8.11.1941, 30.11.1955, 7.06.1968, 30.09.1987 y, la más reciente, de fecha 31.01.2003).

En el proceso de quiebra, se tramita la pieza quinta, con arreglo a lo establecido en los arts. 1382 a 1388 de la anterior LEC y disposiciones concordantes del primero y segundo Código de Comercio. La quiebra debe calificarse por el juez, según el art. 1138 del antiguo Código de Comercio, atendiendo: a) la conducta del quebrado en el cumplimiento de sus obligaciones; b) el resultado de los balances que reflejen su situación; c) el estado en que se encuentran sus libros de contabilidad; d) las causas inmediatas y directas que ocasionaron la quiebra; $y$, e) las reclamaciones que durante el procedimiento se hagan contra el quebrado y sus bienes (arts. 1137 a 1143 del C. de C. de 1829; arts. 886 a 897 del vigente; y, arts. citados de la anterior LEC).

$\mathrm{El}$ art. 886 del C. de C. distingue tres clases de quiebra, a saber: insolvencia fortuita, insolvencia culpable e insolvencia fraudulenta.

A) «Se entenderá quiebra fortuita la del comerciante a quien sobrevinieren infortunios que, debiendo estimarse casuales en el orden regular y prudente de una buena administración mercantil, reduzcan su capital al extremo de no poder satisfacer en todo o en parte sus 
deudas» (art. 887 C. de C.), es decir, que se hubiese descapitalizado. Ferrer Barriendos ${ }^{2}$ considera que la quiebra fortuita se define especialmente por exclusión. Será fortuita la que no es culpable o fraudulenta.

B) Se considerará quiebra culpable o serán reputados quebrados culpables, cuando se origina la quiebra por culpa, imprudencia o negligencia del deudor:

a) Hay casos, que no admiten prueba en contrario, por ser manifiesta la culpabilidad (presunción iuris et de iure), según el art. 888 del C. de C., aunque debe interpretarse de conformidad con la Constitución Española y el derecho fundamental de la persona a la presunción de inocencia y a utilizar los medios de prueba pertinentes para su defensa (art. 24.2 CE). Los casos que cita el mencionado art. 888, no guardan relación con los supuestos enumerados en la nueva Ley concursal.

b) Otros hechos presumen la culpabilidad, mientras el quebrado no pruebe su inocencia (iuris tantum), según el art. 889 del Código de Comercio:

1. " «os que no hubieren llevado los libros de contabilidad en la forma y con todos los requisitos esenciales e indispensables que se prescriben en el Título III del Libro I [arts. 25 a 30], y los que, aun llevándolos con todas estas circunstancias, hayan incurrido dentro de ellos en falta que hubiese causado perjuicio a tercero». Al respecto, se pronuncian las sentencias del TS de 24.04.1984, 22.02.1987, 27.03.1987, 22.04.1987 y 2.03.1990. La inobservancia del requisito de legalización de los libros de contabilidad, en los términos que el Código de Comercio previene, fundamenta la calificación de quiebra culpable. La presunción de inocencia puede ser destruida por la prueba practicada, cuando se alega la sustracción de los libros de contabilidad, según la STS de 8.04.1990.

2. «Los que no hubieren hecho su manifestación de quiebra en el término y forma que se prescribe en el art. 871», es decir, en su texto original: «... presentarse en suspensión de pagos,

2 Ferrer Barriendos, Agustín, «Repercusiones concursales del nuevo Código Penal», en Derecho Concursal II (Cuadernos de Derecho Judicial). Madrid, Consejo General del Poder Judicial, 1996, p. 561. 
dentro de los tres días siguientes al que se hubiere cesado en el pago corriente de sus obligaciones». Virtualmente suprimido y derogado por la reforma, en 1897, del art. 871 del C. de C., que incorporó la siguiente redacción: «... dentro de las cuarenta y ocho horas siguientes al vencimiento de una obligación que no haya satisfecho», según declaran las sentencias del TS de 9.10.1929, 16.05.1956 y 24.04.1984. La doctrina científica mayoritaria (González de Echávarri y Miguel Romero ${ }^{3}$, Garrigues $^{4}$, Torres de Cruells ${ }^{5}$, Sagrera Tizón 6 , Bisbal ${ }^{7}$, Mascarell ${ }^{8}$, Menéndez ${ }^{9}$, Cordón Moreno ${ }^{10}$, y Rojo, Beltrán y Campuzano $^{11}$ ) considera tácitamente derogado este precepto, a partir de la Ley de 26.07.1922.

3..$^{\circ}$ «Los que, habiéndose ausentado al tiempo de la declaración de quiebra o durante el progreso del juicio, dejaren de presentarse personalmente en los casos en que la Ley impone esta obligación, no mediando legítimo impedimento».

Según Ferrer Barriendos ${ }^{12}$ la quiebra culpable es equivalente grosso modo a la quiebra producida por imprudencia grave derivada del descuido de la conducta propia de un ordenado comerciante.

3 González de Echávarri y Vivanco, José M. ${ }^{a}$ y Miguel Romero, Mauro, Comentarios a la Ley de Suspensión de Pagos. Valladolid, Emilio Zapatero (imp.), S.A., p. 153.

4 Garrigues, Joaquín, Dictámenes de Derecho Mercantil. Madrid, Aguirre (imp.), 1976, tomo II, pp. 312-314.

5 Torres de Cruells, Joaquín, La suspensión de pagos. Barcelona, Bosch, 1957, p. 83.

${ }^{6}$ Sagrera Tizón, José M. ${ }^{\mathrm{a}}$, Comentarios a la Ley de suspensión de pagos. 2. ${ }^{\mathrm{a}}$ ed., Barcelona, Bosch, 1989, vol. I, pp. 164-166.

7 Bisbal MÉndez, Joaquín, La empresa en crisis y el Derecho de quiebras (Una aproximación económica y jurídica a los procedimientos de conservación de empresas). Bolonia, Publicaciones del Real Colegio de España (Studia Albornotiana IL), 1986, pp. 150-151.

8 Mascarell Navarro, M. ${ }^{a}$ José, Aspectos procesales de la Ley de suspensión de pagos. Granada, Comares, 1994, pp. 12-13.

9 MenÉndez, Aurelio, «Sobre la reforma del Derecho concursal y el apoyo de los estudios económicos», Revista del Consejo General de la Abogacía Española, núm. 2, septiembre 1994, pp. 6-7. «Breves reflexiones sobre la reforma del Derecho concursal», en Homenaje a José M. ${ }^{a}$ Chico y Ortiz. Coordinador: Juan Luis Gimeno, Madrid, Colegio de Registradores de la Propiedad y Mercantiles de España/Marcial Pons, 1995, pp. 1316-1317.

10 Cordón Moreno, Faustino, Suspensión de pagos y quiebra. Una visión jurisprudencial. Pamplona, Aranzadi, 1995, 3. a edición: 1997, pp. 196-197.

11 Rojo Fernández-Río, Angel, Beltrán SÁnchez, Emilio M. y Campuzano LaGuILlo, Ana Belén, Legislación y Jurisprudencia Concursales. Pamplona, Aranzadi, 1997, p. 109 .

12 Ferrer Barriendos, Agustín, op. cit., p. 561. 
C) «Se reputará quiebra fraudulenta la de los comerciantes en quienes concurra alguna de las circunstancias siguientes» (art. 890 C. de C.):

$\ll 1 .^{a}$ Alzarse con todos o parte de sus bienes.

2. ${ }^{a}$ Incluir en el balance, memorias, libros y otros documentos relativos a su giro o negociaciones, bienes, créditos, deudas, pérdidas o gastos supuestos.

3. ${ }^{a}$ No haber llevado libros o, llevándolos, incluir en ellos, con daño de tercero, partidas no sentadas en lugar y tiempo oportunos.

$4{ }^{a}$ Rasgar, borrar o alterar de otro modo cualquiera el contenido de los libros, en perjuicio de tercero.

$5{ }^{a}$ No resultar de su contabilidad la salida o existencia del activo de su último inventario, y del dinero, valores, muebles y efectos, de cualquiera especie que sean, que constare o se justificare haber entrado posteriormente en poder del quebrado.

6. ${ }^{a}$ Ocultar en el balance alguna cantidad de dinero, créditos, géneros $u$ otra especie de bienes o derechos.

7. ${ }^{a}$ Haber consumido y aplicado para sus negocios propios, fondos o efectos ajenos que le estuvieren encomendados en depósito, administración o comisión.

8. ${ }^{a}$ Negociar, sin autorización del propietario, letras de cuenta ajena que obraren en su poder para su cobranza, remisión u otro uso distinto del de la negociación, si no hubiere hecho a aquél remesa de su producto.

9. ${ }^{a} \mathrm{Si}$, hallándose comisionado para la venta de algunos géneros o para negociar créditos o valores de comercio, hubiere ocultado la operación al propietario por cualquier espacio de tiempo.

10. Simular enajenaciones, de cualquier clase que éstas fueren.

11. Otorgar, firmar, consentir o reconocer deudas supuestas, presumiéndose tales, salvo la prueba en contrario, todas las que no tengan causa de deber o valor determinado.

12. Comprar bienes inmuebles, efectos o créditos, poniéndolos a nombre de tercera persona, en perjuicio de sus acreedores.

13. Haber anticipado pagos, en perjuicio de los acreedores.

14. Negociar, después del último balance, letras de su propio giro a cargo de persona en cuyo poder no tuviere fondos ni crédito abierto sobre ella, o autorización para hacerlo.

15. Si, hecha la declaración de quiebra, hubiere percibido y aplicado a usos personales dinero, efectos o créditos de la masa, o distraído de ésta alguna de sus pertenencias».

D) «La quiebra del comerciante, cuya verdadera situación no pueda deducirse de sus libros, se presumirá fraudulenta, salvo prueba en contrario», según el art. 891 del C. de C. 
Pido excusas por la detallada enumeración de hechos y circunstancias, que pueden dar lugar a la calificación de la quiebra o de la suspensión de pagos como culpable o fraudulenta, a causa de su provechosa comparación con los supuestos que se contemplan en los citados arts. 164 y 165 de la nueva Ley concursal, objeto de las siguientes observaciones.

\section{En el nuevo concurso}

El artículo 163 dispone: «2. El concurso de acreedores se calificará como fortuito o como culpable...». Interesa recordar que se pretende calificar la conducta del deudor, antes (dos años) y después de la declaración de concurso (durante la tramitación del procedimiento), en relación con los hechos descritos en los arts. 164 y 165.

\subsection{Fortuito}

Se calificará como concurso fortuito cuando no proceda la calificación de culpable.

\subsection{Culpable}

Conviene transcribir de la exposición de motivos: «La última calificación [culpable] se reserva a aquellos casos en los que en la generación o agravación del estado de insolvencia hubiera mediado dolo o culpa grave del deudor, o de sus representantes legales, administradores o liquidadores.

La ley formula el criterio general de calificación del concurso como culpable y a continuación enuncia una serie de supuestos que, en todo caso, determinan esa calificación, por su intrínseca naturaleza, y otra de supuestos que, salvo prueba en contrario, son presuntivos de dolo o culpa grave, por constituir incumplimiento de determinadas obligaciones legales relativas al concurso».

El concurso se calificará como culpable cuando en la generación o agravación del estado de insolvencia hubiera mediado dolo o culpa grave del deudor o, si los tuviese, de sus representantes legales y, en caso de persona jurídica, de sus administradores o liquidadores, de derecho o de hecho (art. 164). Conviene recordar el art. 2.2: "Se encuentra en estado de insolvencia el deudor que no puede cumplir regularmente sus obligaciones exigibles». 
El art. 260 del Código Penal sanciona el fraude en las situaciones de insolvencia concursal, es decir, cuando la crisis económica o la insolvencia sea causada o agravada dolosamente por el deudor, desvinculándose de las calificaciones de la quiebra. Se trata de un delito de resultado, que requiere el perjuicio a los acreedores y no es un delito de enriquecimiento. Delito de lesión, por tanto, y no de peligro. Delito doloso, que excluye la imprudencia. Introduce el citado artículo 260 el término de «crisis económica», concepto jurídico indeterminado, a no ser que se mencione como sinónimo de insolvencia, que para la doctrina mercantil y financiera presenta matices diferenciados. El concepto de insolvencia no es unívoco, pues se extiende a zonas imprecisas que van desde no pagar (sobreseimiento en el cumplimiento de las obligaciones) hasta no poder pagar, total o parcialmente, por carecer de patrimonio neto (activo inferior al pasivo), es decir, por pérdida total del capital social (descapitalización, no desbalance). Considero que se ha pretendido asimilar «crisis económica» con iliquidez o insolvencia provisional e «insolvencia» con descapitalización o ausencia de recursos propios.

La actuación dolosa del deudor presupone mala fe, malicia o voluntariedad, respecto del resultado dañoso, y la culpa grave requiere la infracción de los deberes más elementales en la observancia de la diligencia debida, bien como buen padre de familia (arts. 1104, 1889 y 1903 in fine del C. civil), bien como ordenado empresario y representante leal (art. 127.2 TRLSA).

\subsubsection{Supuestos De CUlPABILIDAD}

El apartado 2, del mencionado art. 164, dispone que, en todo caso, el concurso se calificará como culpable cuando concurra cualquiera de los siguientes supuestos:

«1. ${ }^{\circ}$ Cuando el deudor legalmente obligado a la llevanza de contabilidad incumpliera sustancialmente esta obligación, llevara doble contabilidad o hubiera cometido irregularidad relevante para la comprensión de su situación patrimonial o financiera en la que llevara».

Se refiere al cumplimiento de los deberes contables, como actualmente se previene en los citados arts. 888,889 y 890 del C. de C., para la calificación de la quiebra o de la suspensión de pagos, declarada como insolvencia definitiva, aunque habrá que esperar a la doctrina científica y de los Tribunales de Justicia, para concretar el alcance del incumplimiento sustancial de la obligación de llevanza de contabilidad, salvo que se acuda a preceptos del ordenamiento tribu- 
tario (art. 50 ${ }^{13}$ LGT de 1963) y a la jurisprudencia (Sentencias de la AN, Sala de lo Contencioso-Administrativo, de fechas 20.06.1997 y 30.03.2000, que menciona las SSTS de fechas 16.07.1988, 13.03.1989, 9.01.1992 y 5.05.1993). La no llevanza de la contabilidad, en la forma y con todos los requisitos que prescribe el C. de C., puede asimilarse al incumplimiento sustancial de las obligaciones contables, que menciona el art. 50 de la LGT, y para precisar su significado se transcribe el criterio de la Sala de lo Contencioso-Administrativo de la Audiencia Nacional, en la referida sentencia de 20.06.1997: «Fundamentos de Derecho: Tercero. ...la doctrina jurisprudencial ha venido entendiendo como supuestos de incumplimiento sustancial de las obligaciones contables, casos de ausencia de llevanza de los libros obligatorios, exigidos por el Código de Comercio, como su llevanza parcial, así como la no aportación de las facturas, o su aportación, también parcial, que no permitan la comprobación o contraste con lo reflejado en los libros (Tribunal Supremo sentencias 16 julio 1988, 13 marzo 1989, 9 enero 1992 y 5 mayo 1993; entre otras). Cuarto. ... la actora no conservaba los justificantes de ingresos y gastos ocasionados en el desarrollo de su actividad... Estas irregularidades impiden la constatación de la realidad contable de la mercantil recurrente...».

Puede servir de interpretación, en el supuesto del art. 164.2.1. ${ }^{\circ}$, respecto del incumplimiento sustancial de deberes contables, la jurisprudencia ad hoc, en el vigente proceso de quiebra, a saber:

-Sentencias del TS de 24.04.1984, 22.02.1987, 27.03.1987, 22.04.1987 y 2.03.1990. La inobservancia del requisito de legalización de los libros de contabilidad, en los términos que el Código de Comercio previene, fundamenta la calificación de quiebra culpable. La presunción de inocencia puede ser destruida por la prueba practicada, cuando se alega la sustracción de los libros de contabilidad, según la STS de 8.04.1990.

—La STS de 24.04.1901, recogida por Pastor y Bustos ${ }^{14}$, declara: «El comerciante que no llevando Libro de Inventarios y Balances se declarare en quiebra, procede le sea calificada de fraudulenta y no le

${ }^{13}$ Cuando la falta de presentación de declaraciones o las presentadas por los sujetos pasivos no permitan a la Administración el conocimiento de los datos necesarios para la estimación completa de las bases imponibles o de los rendimientos o cuando los mismos ofrezcan resistencia, excusa o negativa a la actuación inspectora o incumplan sustancialmente sus obligaciones contables, las bases o rendimientos se determinarán en régimen de estimación indirecta...».

14 PAstor y Bustos, F., El Código de Comercio interpretado por la Jurisprudencia del Tribunal Supremo. Madrid, Hijos de Reus Editores, 1911, vol. I, p. 410. 
es de aplicación el núm. 1 de este artículo 889, porque la calificación más atenuada de quiebra culpable sólo alcanza al que, llevando todos los libros que la ley exige, no se atempera, en cuanto a su forma y redacción a los requisitos intrínsecos e extrínsecos que el Código tiene establecidos». Dicha STS, citada también por Gay de Montellá15, añade: "La sola omisión del Libro de Inventarios en la contabilidad de un comerciante, es causa suficiente de que se declare fraudulenta la quiebra del mismo... porque siendo cada uno de estos libros parte integrante de un solo todo, o de un sistema de contabilidad restablecido,... la falta de uno sólo afectaría a todo el sistema, que dejará de ser, por consecuencia de semejante omisión, lo que la ley quiere y tiene establecido en interés público y del comercio en general...».

-El mismo autor Pastor y Bustos ${ }^{16}$ refiere la STS de 4.05.1901: «El comerciante que declarado en quiebra no presentare libros de contabilidad, memoria ni balance, alegando fueron destruidos aquéllos en incendio ocurrido en su casa, puede ser calificado como quebrado fraudulento si la Sala sentenciadora no estimare probada tal afirmación, que al quebrado correspondió justificar».

—STS del 18.02.1911, citada por Gay de Montellá17: «La presunción de fraudulencia establecida en este artículo no puede tener aplicación al caso en que, si por la pérdida de los libros no es dable deducir la verdadera situación del quebrado, no es imputable a éste esa pérdida, y, por tanto, no es obra suya la causa que impide conocer su situación en la vida mercantil».

—STS del 21.02.1976: "... al momento de la declaración de quiebra, sólo existían los libros "Diario", "Mayor" y el de "Actas" faltando, los de "Copiador de Cartas y Telegramas" y el de "Inventarios y Balances" y que en lo que se refiere a este último ha de estimarse su falta, con entidad suficiente para el pronunciamiento de fraudulenta, pues dada la importancia del mismo, es el que patentiza al final de cada ejercicio el verdadero estado económico del negocio. La doctrina jurisprudencial -sentencias de 17.10 y 10.06.1982-establece, como comprendidos en el art. 890.3 cualquiera de los necesarios que se expresan en el art. 33. Es evidente, que aquellos preceptos sustantivos, 891 y 890-3, obligan a los Tribunales a declarar "fraudulenta" la [quiebra] de los comerciantes que incumplan en cuanto a sus libros de

15 Gay de Montellá, R., Código de Comercio anotado con la Jurisprudencia del Tribunal Supremo y Resoluciones de la Dirección General de Registros hasta 31 de diciembre de 1917. Barcelona. Perelló, 1918, tomo I, pp. 22 y 256-257.

16 Pastor y Bustos, F., op. cit., vol. I, pp. 413-414.

17 GAy de Montellá, R., op. cit., p. 258. 
contabilidad los deberes que con relación a ellos se impone en el Título Tercero del Libro Primero de la Ley sustantiva citada, ya que ello constituye una garantía o salvaguarda de los intereses de quienes se relacionen con ellos y evitan sea imposible, en caso necesario, conocer su verdadera situación económica, cuya obligación es de todo punto ineludible».

—STS de 10.03.1980: «Resulta plenamente acreditado la concurrencia de la circunstancia determinada en el párrafo $3 .^{\circ}$ del artículo 890 del Código de Comercio, que preceptúa la calificación de fraudulenta a la quiebra de comerciante que no hubiera llevado los libros de contabilidad de los que exige el artículo 33 del Código de Comercio».

-STS 22.11.1985: «La calificación de la quiebra, como fraudulenta, se asienta no solamente en la circunstancia de no llevar la entidad recurrente el Libro de Inventarios y Balances, sino también en irregularidades relativas al Libro Mayor, a que los datos del balance, ya declarada la quiebra, no se corresponden con la realidad, a la circunstancia de "haberse emitido obligaciones con garantía hipotecaria para pago de maquinaria adquirida, no se ha pagado la misma, desconociéndose el destino de la suma obtenida con la emisión, y por impago de las obligaciones emitidas se ejecuta la garantía hipotecaria y, por último, no se ha acreditado la titularidad de las patentes de la quebrada", circunstancias determinantes de la calificación que se incardinan, aunque no sean objeto de cita expresa, en otros supuestos del citado 890 del Código mercantil. ... Es reiterada doctrina de esta Sala la que proclama que el Código de Comercio concede tanta trascendencia a los libros de comercio, que en su artículo 33 ordena llevar a los comerciantes, que utiliza el adverbio de modo "necesariamente", de aquí que la ausencia, bien total o parcial, en dicha llevanza, determina que la quiebra, por él mismo provocada, haya de ser calificada como de fraudulenta, conforme dispone el párrafo $3 .^{\circ}$ del artículo 890 de dicho Cuerpo legal».

—STS 5.07.1989: «... de ahí que esta Sala tenga determinado que la ausencia de libros, por alegarse haber sido sustraídos, no impide la posibilidad de declarar al comerciante en situación de quiebra fraudulenta, cuando esa apreciación judicial emana de aspectos fácticos, no controvertidos adecuadamente y vinculantes en casación que enmarcan en el ámbito de otras circunstancias del art. 890 C. de C., además de la taxativamente prevista en la $3 .^{a}$ de dicha norma...».

—STS 17.04.1990: «... el dato capital, que ya estuvo presente en el informe de los interventores de la suspensión de pagos que precedió, en meses, a la situación de quiebra, constituido por la no llevanza de anotación alguna en los libros obligatorios Diario, Inventario y de Ba- 
lances (art. 33 C. de C.), a todo lo largo del año anterior a la suspensión, concretamente desde diciembre de 1982, determinante, según aquel informe, "de no haber podido analizar de forma global las operaciones previas a la suspensión..., ni establecer los valores de las distintas cuentas", subsiste agravado por el tiempo, a la hora de la quiebra voluntaria, como textualmente pone de manifiesto el fundamento de derecho $2 .^{\circ}$ de la sentencia del juzgado y valora la de la apelación, a efectos del art. 890.3 y presunción del 891 C. de C., teniendo a la vista, además de aquella incuestionable falta de documentación básica generadora, según la intervención dicha, de la "dificultad de profundizar en determinados temas", la confusión contable que, con detalle, la propia sentencia de $1 .^{a}$ Instancia extrae de la documentación existente...».

-STS 18.04.1990: «Cuarto. El C. de C. concede tanta trascendencia a los libros de contabilidad - que en su art. 33 ordena llevar a los comerciantes-que utiliza el adverbio de modo "necesariamente", de aquí que la ausencia, bien total o parcial, en dicha llevanza, determina que la quiebra, por el mismo provocada, haya de ser calificada como de fraudulenta, conforme dispone el art. 890.3 de dicho cuerpo legal (SS 5.11.1956, 7.02.1964, 10.10.1969 y 21.11.1985); ya que la verdadera situación de la entidad quebrada no ha podido deducirse de sus libros, lo que abona en presunción de fraudulencia (S. 2.02.1980); caso distinto de cuando la falta de libros se debe a causas ajenas a la voluntad del quebrado, como es el supuesto de robo (S. 1.12.1985). Pero, sobre todo, las circunstancias que definen los arts. 890 y 891 C. de C. implican una cuestión de hecho (S. 4.06.1987), que ha deducido la Sala de instancia del resultado de las pruebas...».

—Baró Casals ${ }^{18}$ cita, entre otras, la sentencia, de 19.01.1994, de la AP de Barcelona: «Segundo. Cierto es que el informe del señor comisario, no desmentido de contrario y debidamente valorado por el juez a quo, pone de manifiesto la inexistencia de asientos en los denominados "libros" Diario, de Inventarios y Mayor y tan sólo dos transcripciones en el libro de Actas y una en el de Balances (libros al parecer originarios, encuadernados y legalizados el 27 de diciembre de 1990), y que la sentencia de instancia valorando tales defectos trae a colación el párrafo 1 del artículo 889 del Código de Comercio (quiebra culpable por no llevar libros en la forma y con los requisitos legales)... y concluir la existencia de quiebra fraudulenta, por no poder deducir de

18 Baró CASAls, Antonio, La quiebra. Legislación y jurisprudencia sistematizadas, Barcelona, Cedecs, 1996, pp. 937-938. 
los libros la verdadera situación de la quebrada (890.3 y 891 del propio Código). Tercero. Llevada la contabilidad de la empresa por sistemas informáticos y mediante hojas móviles, como se acredita en los autos..., es evidente que la legalización de los libros obligatorios (artículo 33 del Código de Comercio) podía realizarse a posteriori, como permite el artículo 297 del Reglamento del Registro Mercantil, dentro de los cuatro meses siguientes a la finalización del ejercicio. No parece, por tanto, que "strictu sensu" los libros entregados al comisario sean realmente los de la empresa (a excepción quizás del de Actas), sino que por un prurito formal se legalizaron libros encuadernados, en vez de encuadernar y legalizar las hojas móviles... Cuarto. Constan en autos, sin raspaduras ni intercalados, balances de situación, cuentas de pérdidas y ganancias y otras cuentas de 1990 (los últimos a fecha 31 de diciembre)... La quebrada podía legalizar, por tanto, los libros del ejercicio de 1990, en los cuatro meses siguientes a la fecha de cierre (31 de diciembre), por lo que a la fecha de presentación de la quiebra (15 de febrero de 1991) estaba cubierto por las previsiones del artículo 297 del Reglamento del Registro Mercantil. Es, además, evidente que puede deducirse una situación contable de la empresa (se refleja una disminución del activo, de enero a diciembre de 48 a 39 millones de pesetas aproximadamente y unas pérdidas anuales de 8.883 .346 pesetas),... por lo que queda destruida la presunción del artículo 891 del Código de Comercio. La legalización supondría garantía adicional sobre la realidad de los asientos, pero la documental acredita que existía contabilidad suficiente. Quinto. No se trata pues de un supuesto de ausencia total o parcial de la llevanza de los libros (sentencias del Tribunal Supremo de 24 de abril de 1901, 17 de junio de 1902, 5 de noviembre de 1956, 7 de febrero de 1964, 6 de diciembre de 1966, 13 de octubre de 1969 y 22 de noviembre de 1985), pues los asientos se han venido efectuando con regularidad tanto respecto a Diario (aunque con enmendados por tratarse de un borrador -folios 174 a 317-) como respecto a Inventarios y Balances y Libro Mayor (configuradas sus partidas conforme a técnicas contables modernas en cuentas y Balances de sumas y saldos, Explotación y Situación). Tampoco se trata de un caso de no llevanza de libros (sentencias del Tribunal Supremo de 19 de mayo de 1983, 27 de abril de 1987 y 17 de diciembre de 1991) sino, en definitiva, de una situación de falta de formalización contable mediante la encuadernación y legalización de las hojas móviles de contabilidad. Ningún elemento de juicio aparece en los autos para interpretar que tales defectos oculten fraude o dolo de la quebrada y su propia existencia destruye la presunción "iuris et de iure" del artículo 890.3 
del Código de Comercio. Sexto. Cierto es que estos libros de contabilidad no se han llevado en la forma y con los requisitos esenciales $e$ indispensables que se prescriben en los artículos 33 y siguientes del Código de Comercio, pues no sólo falta la legalización sino que presentan defectos de redacción y de concepto. Todo ello supone la declaración de quiebra culpable al amparo del número 1 del artículo 889 del propio texto legal».

En cuanto al supuesto de llevanza de doble contabilidad, interesa la STS (Sala de lo Penal), de 30.01.1991: «Segundo. El juez civil calificó de fraudulenta por él declarada, por concurrir las circunstancias previstas en el artículo 891 del Código de Comercio,... según los hechos declarados probados de la sentencia recurrida, en los que asienta la información cardinal de que la quebrada llevaba constantemente una doble contabilidad sistematizada que, por completo, afectaba a todo el montante comercial de la empresa, de manera que un gran número de operaciones comerciales quedaban sólo reflejadas en la contabilidad oculta, llamada en la empresa Caja B, y detraídas al juego y resultado de la contabilidad transparente asentada en los libros oficiales que, por la razón dicha, no reflejaban la situación real de la empresa, y esa doble contabilidad que permitía al procesado ocultar en el balance cantidades en dinero, que procedía de las operaciones comerciales realizadas por la empresa, y del que en parte se lucraba, pone de manifiesto el ánimo de defraudar a los acreedores sociales, pues toda doble contabilidad tiene por finalidad ánimo defraudatorio, y el perjuicio real causado a estos al detraer del patrimonio alguna cantidad es causa, o al menos concausa determinante de la quiebra económica acaecida...».

Por último, cuando se hace referencia a irregularidad relevante [en la contabilidad], para la comprensión de la situación patrimonial o financiera, cabe traer a colación lo dispuesto en la SAP de Bizkaia, de 3.11.1999: «Fundamento Jurídico Segundo. Las premisas en las que basa la sentencia recurrida la calificación de la quiebra como fraudulenta, se concretan en las dos siguientes: $\left.1 .^{a}\right)$ no ser el conjunto contable ocupado a la quebrada fiel reflejo de la realidad, resultando por ello insuficiente a los fines de control o información a los que debe tender $u$ orientarse una adecuada administración; $y, 2{ }^{a}$ ) la llevanza defectuosa de los libros de comercio, al no constar la memoria en el Libro de Inventarios y Cuentas anuales. La primera de las señaladas premisas se establece en la sentencia en función de las irregularidades que en la misma se achacan a la contabilidad de la quebrada, las que a su vez se concretan: a) en la existencia de operaciones contables sin soporte físico (facturas) y en la existencia de soportes físicos 
(albaranes) no contabilizados; b) en la existencia de descuentos de efectos sin soporte en facturas, esto es, de efectos ficticios; y c) en la existencia de grandes diferencias de... En definitiva, que las irregularidades contables a través de las que se construye, en la sentencia, recurrida la primera premisa de imputación, esto es, la de no ser el conjunto contable ocupado a la quebrada fiel reflejo de la realidad, resultando por ello insuficiente a los fines de control o información a los que debe tender u orientarse una adecuada administración, constituyen circunstancias suficientemente acreditadas y de procedente subsunción, dados sus términos, en las que reseñadas como $2 .^{a}$ y $6 .{ }^{a}$, en el artículo 890 del Código de Comercio, obligan a reputar la quiebra fraudulenta...».

«2. ${ }^{\circ}$ Cuando el deudor hubiera cometido inexactitud grave en cualquiera de los documentos acompañados a la solicitud de declaración de concurso o presentados durante la tramitación del procedimiento, o hubiera acompañado o presentado documentos falsos». Concordante con los arts. 6.2 y 3,21.1.3. $.^{\circ}, 45,46,96$ y 100.4 y 5, de esta Ley.

Puede servir de orientación, para delimitar el concepto de documento, la STS (Sala de lo Penal), de 19.01.1998: «Fundamentos de Derecho. Séptimo... Con carácter previo, conviene partir de la doctrina general que, en orden a este vicio sentencial, se ha pronunciado la jurisprudencia de esta Sala que, de manera reiterada, viene delimitando el concepto de documento, requiriendo en primer término que se trate de un documento en sentido estricto, entendiendo por tal el escrito, en sentido tradicional, o aquella otra cosa que, sin serlo, pueda asimilarse al mismo, por ejemplo, un diskette, un documento de ordenador, un vídeo, una película, etc., con un criterio moderno de interacción de las nuevas realidades tecnológicas, en el sentido en que la palabra documento figura en algunos diccionarios como "cualquier cosa que sirve para ilustrar o comprobar algo" (obsérvese que se trata de una interpretación ajustada a la realidad sociológica, puesto que, al no haber sido objeto de interpretación contextual y auténtica, puede el aplicador del Derecho tener en cuenta la evolución social), siempre que el llamado "documento" tenga un soporte material, que es lo que, sin duda exige la norma penal. (Por todas, SSTS 1114/1994, de 3 junio, 1763/1994, de 11 octubre y 711/1996, de 19 octubre). En la actualidad dicha fórmula jurisprudencial tiene adecuada correspondencia en la norma contenida en el artículo 26 del nuevo Código Penal, según el cual "A los efectos de este Código se considera documento todo soporte material que exprese o incorpore datos, hechos o narraciones con eficacia probatoria o cualquier otro tipo de relevancia jurídica”. Con arreglo a la 
nueva fórmula legal, la interpretación literal del artículo 26 del Código penal de 1995 resulta insatisfactoria, y por ello, se impone hallar otra. Así, puede concluirse que documento, a efectos penales, es el resultado de combinar un soporte material y datos, hechos o narraciones; caracterizándose aquélla por las notas siguientes: a) En primer término, el documento al ser una materialización, debe de constar en un soporte indeleble...; b) Otra nota es que tenga procedencia humana. Se trata de que el contenido del documento resulte atribuible a una persona...; c) También el contenido de la declaración debe ser comprensible de acuerdo a los usos sociales, es decir, significativa en sí misma...; d) También se requiere la entrada en el tráfico jurídico...; e) Por último, el documento válido es el documento original y no tienen tal carácter las copias ni fotocopias. Sin embargo, esta afirmación es cada vez más relativa al aumentar el tráfico jurídico $y$, por tanto, el número de documentos...».

El art. 261 del Código Penal castiga a quien en procesos concursales presenten, a sabiendas, datos falsos relativos al estado contable, con el fin de lograr indebidamente la declaración de aquellos.

La inexactitud grave, en los documentos presentados por el deudor, entraña apartarse de la realidad y de la fidelidad de los datos aportados, y es causa para la calificación de concurso como culpable, al igual que sucederá cuando de documentos falsos se tratase, es decir, no auténticos, fingidos o simulados, faltos de veracidad. Quizá, la inclusión de esta presunción de culpabilidad, evite algunos fraudes procesales, saliendo al paso del abuso que cunde, a veces, en el escenario judicial, cuando se acompañan a la solicitud de declaración de suspensión de pagos o de quiebra, al sancionar la presentación de documentos inexactos o falsos, v. g. las cuentas anuales (balance, cuenta de pérdidas y ganancias y memoria) o estados financieros intermedios.

García-Cruces ${ }^{19}$ advierte: «... el legislador supone la culpabilidad en el concurso cuando el concursado hubiera cometido "inexactitud grave" en los documentos que acompañan la solicitud de concurso o que entregara durante la tramitación de este procedimiento. Pues bien, la delimitación correcta de tal supuesto de hecho no deja de estar exenta de problemas, a la par que ocasiona serias dudas sobre la conveniencia de tal proceder, como bien lo atestigua su falta de acogida en los precedentes inmediatos del PLC (cfr. Art. 205.5. ${ }^{\circ}$ PAPLC

19 García-Cruces, José Antonio, «El problema de la represión de la conducta del deudor», p. 267. La reforma de la legislación concursal, Jornadas, Madrid, 6 a 10 de mayo de 2002, Marcial Pons, Ediciones Jurídicas y Sociales, S. A., Madrid, 2003. 
de 1995). Si comparamos esta segunda previsión respecto del supuesto de la falsedad también acogido en la regla proyectada, me parece que podrán concretarse en las exigencias que han de darse en el supuesto de hecho de "inexactitud grave". Así, la conducta contemplada requiere, en primer lugar, que se produzca el mismo resultado que en el supuesto anterior; esto es, que la información que se ofrece en la documentación entregada no se ajuste a la realidad. Ahora bien, de igual modo, será necesario que ese resultado de discordia entre lo expresado documentalmente y la realidad de la situación patrimonial financiera no pueda tener su origen en la falsedad como conducta intencional y querida por el deudor común, sino, mejor, en su involuntariedad. En definitiva, el supuesto de hecho ha de ser reconducido al de error en la noticia dada a través de los documentos».

«3. ${ }^{\circ}$ Cuando la apertura de la liquidación haya sido acordada de oficio por incumplimiento del convenio debido a causa imputable al concursado». Concordante con lo dispuesto en los arts. 140, 142.3 y 4, $143.1 .5 .^{\circ}$ y 169.3 .

La Sentencia, que declare el incumplimiento del convenio, deberá expresar la causa del mismo, como previene el art. 172.120 de esta Ley y a lo que coadyuva lo dispuesto en el art. $169.3^{21}$, en relación con el art. $167.2^{22}$, a los que me referiré en el epígrafe 2.5. García-Cruces ${ }^{23}$ señala: «...parece razonable que concluyamos limitando la aplicación de esta regla de presunción de concurso culpable al incumplimiento del convenio que fuera doloso o con culpa grave del concursado».

«4. Cuando el deudor se hubiera alzado con la totalidad o parte de sus bienes en perjuicio de sus acreedores o hubiera realizado cualquier acto que retrase, dificulte o impida la eficacia de un embargo en cualquier clase de ejecución iniciada o de previsible iniciación».

Presentan destacado interés los delitos tipificados en los arts. 257 y 258 del CP, relativos al alzamiento de bienes en perjuicio de acreedores,

${ }^{20}$ La sentencia declarará el concurso como fortuito o como culpable. Si lo calificara como culpable, expresará la causa o causas en que se fundamente la calificación.

${ }^{21}$ En los casos a que se refiere el apartado 2 del artículo 167, el informe de la administración concursal y, en su caso, el dictamen del Ministerio Fiscal se limitarán a determinar las causas del incumplimiento y si el concurso debe ser calificado como culpable.

22 Cuando se hubiera formado la sección de calificación como consecuencia de la aprobación de un convenio con el contenido previsto en el número $1 .^{\circ}$ del apartado 1 del artículo $163 \mathrm{y}$, con posterioridad, éste resultare incumplido...

23 García-Cruces, José Antonio, op. cit., pp. 271-272. 
dada su relevancia en la antesala del fenómeno concursal, aunque estos tipos penales no se encuentren vinculados directamente a los procesos concursales, salvo la mención del art. 257: «3. Este delito será perseguido aun cuando tras su comisión se iniciara una ejecución concursal». Respecto de la modalidad de alzamiento, regulada en el art. 519 del anterior CP, en el vigente se tipifican dos nuevas conductas: a) el alzamiento procesal o procedimental del art. 257.1.2. ; y, b) el alzamiento para eludir la responsabilidad civil derivada del delito, ex art. 258 del CP.

Puede servir de guía, en este supuesto, la jurisprudencia dedicada al mismo hecho, en el vigente proceso de quiebra (art. 890.1 del C. de C.), a saber:

—Sentencia del TS de 10.12.1985, recogida por Baró Casals ${ }^{24}:$ «... ha quedado probado mediante recibos el pago de escrituras de compra de un chalet a nombre de la esposa del administrador de la indicada sociedad quebrada, generando en consecuencia, con independencia del resultado que deparase el examen que pudiera llevarse a cabo de la expresada contabilidad que se dice sustraída, supuestos de fraudulencia comprensibles, cual se aprecia en la sentencia recurrida, en el ámbito de las circunstancias quinta y doce del artículo ochocientos noventa del Código de Comercio, dado que, con abstracción de los libros que se aduce han sido objeto de sustracción, no puede negarse que de tener un normal destino perceptor contable aquella suma superadora de los veinte millones de pesetas y los seis millones obtenidos, por préstamo personal, del Banco Occidental, S.A., fácil sería a la entidad quebrada, de no existir anormalidad alguna que enmarque en la circunstancia quinta de dicho artículo ochocientos noventa, acreditarlo mediante medios probatorios independientes de la contabilidad reflejada en los relacionados libros que se dicen sustraídos, y no lo ha efectuado en tiempo adecuado y oportuno, y de tener una causa normal la relacionada adquisición del expresado chalet, no encajable en consecuencia dentro del ámbito de la precitada circunstancia doce del repetido artículo ochocientos noventa, también fácil hubiera sido destruir la lógica presunción de estarse en presencia de compra puesta a nombre de tercera persona en perjuicio de acreedores, toda vez que no resulta comprensible en el normal actuar humano el que, sin acreditación de causa justificante alguna y estando abocado a un desfase económico perjudicial, que incluso llevó a la solicitud de declaración

${ }^{24}$ Baró CASAls, Antonio, op. cit., p. 968. 
de quiebra, satisfaga el importe de adquisición que se pretende efectúa con desvinculación patrimonial del quebrado que atiende a abonos a cargo de la adquisición llevada a cabo».

—Baró Casals ${ }^{25}$ cita la STS de 19.10.1991: "No se incluyó en la contabilidad un terreno sito en..., lo que puede incluirse en el núm. $6^{\circ}$ del propio precepto» [890].

«5. ${ }^{\circ}$ Cuando durante los dos años anteriores a la fecha de la declaración de concurso hubieran salido fraudulentamente del patrimonio del deudor bienes o derechos». Concordante con lo dispuesto en el art. 71, que regula las acciones de reintegración, aunque en éste no se requiere intención fraudulenta, pues tan sólo es suficiente que hubiese sido perjudicial para la masa activa, y está relacionado con el posible delito de alzamiento, si causase perjuicio a los acreedores. Debe probarse el ánimo defraudatorio, modalidad de conducta que constituye un comportamiento del deudor en fraude de acreedores, es decir, que la acción causante de la salida de bienes o derechos de su patrimonio ha contribuido al estado de insolvencia.

Puede servir de ayuda hermenéutica la jurisprudencia dedicada a este hecho en el vigente proceso de quiebra, sobre ocultación o desaparición de bienes (art. 890. 5. ${ }^{\circ}, 10 .^{\circ}$ y $12 .^{\circ}$ ), la STS de 6.05.1983. Baró Casals $^{26}$ selecciona las siguientes resoluciones: STS de 24.06.1927, SAT de Barcelona de 15.10.1987; SAP de Teruel, de 9.11.1996, SAP de Barcelona, de 8.07.1998: "Fundamentos de Derecho. Octavo. La apropiación o alzamiento de bienes fundamenta la sindicatura: 1) en la desaparición del material de oficina, que detalla, de herramientas; y de vehículos en poder de la quebrada; lo que está reconocido por escrito de 27 de mayo de 1994 de la quebrada, ignorándose el paradero en muchos casos, y sin que conste el ingreso en caja de contraprestación alguna en otros, en que se dispuso a favor de terceros vinculados a la administración de la empresa; 2) en la descapitalización por anticipos a administradores con ulteriores modificaciones de la denominación de la cuenta, que pasa a identificarse y traspasarse sucesivamente como "dividendo a cuenta", "Máximo M.", e integrarse finalmente en "deudores diversos", omitiendo el título de la cuenta en el balance de comprobación de sumas y saldos; y 3) la existencia de dividendos pendientes de desembolso. Noveno. La falta de justificación convincente de la desaparición de bienes y su enajenación a terceros vinculados a los

25 Baró Casals, Antonio, op. cit., p. 969.

26 Baró CAsals, Antonio, op. cit., pp. 946-947. 
administradores de la sociedad, sin desembolso de las contraprestaciones correspondientes - la quebrada se ha limitado a una genérica negativa-, integran la circunstancia primera del artículo 890 del Código de Comercio, sin que lo expuesto quede enervado por el resultado de las diligencias penales seguidas a instancia de la sindicatura, toda vez que, como reitera unánime jurisprudencia (por todas, sentencias de 13 septiembre 1985 y 17 mayo 1988), las resoluciones que se dicten en la jurisdicción penal no producen excepción de cosa juzgada en la civil, salvo cuando se trata de hechos declarados probados, en las condenatorias, o en la declaración de no haber existido los mismos en las absolutorias».

García-Cruces ${ }^{27}$ considera: «La inserción de esta conducta como supuesto de hecho al que se le anuda la presunción de concurso culpable es absolutamente acertada y resulta totalmente oportuna. En efecto, la realización de actos de disposición fraudulenta que se produjeran en la época que fija la norma conlleva, por su propio significado, una alteración de la situación patrimonial del deudor común, determinando el origen o, al menos, el agravamiento de su futuro estado de insolvencia. La calificación de tales actos como fraudulentos afirma la coherencia de esta presunción respecto del criterio general de calificación del concurso como culpable, pues asegura la concurrencia de dolo en el deudor común al llevar a cabo tales actos de disposición patrimonial».

«6. ${ }^{\circ}$ Cuando antes de la fecha de la declaración de concurso el deudor hubiese realizado cualquier acto jurídico dirigido a simular una situación patrimonial ficticia». Lo ficticio se contrapone a imagen fiel, macroprincipio de Derecho contable, que se destaca en el art. 34.2 del C. de C. y el art. 172 del TRLSA.

Permitirá su adecuada comprensión, la solución hermenéutica dada por la jurisprudencia a este hecho, en el vigente proceso de quiebra, a saber:

—Sentencia TS del 4.05.1987: «... la responsabilidad del patrimonio ganancial, existente con anterioridad a la disolución y liquidación de la sociedad del mismo carácter, perviva al efecto de que sobre los bienes que integraban dicho patrimonio puedan hacerse efectivas las deudas contraídas por el marido en el ejercicio de su comercio que, con el conocimiento y sin oposición expresa de la esposa, venía

27 García-Cruces, José Antonio, op. cit., p. 272. 
desarrollando, según al respecto autorizaba la preceptiva contenida en los arts. 6 y 7 CC, derivando de ello que el negocio jurídico del otorgamiento de capitulaciones, constante matrimonio, estableciendo el régimen de separación de bienes en sustitución del de gananciales, al no poder perjudicar el derecho de los acreedores del esposo comerciante, para hacer efectivos sus créditos sobre todos los bienes que integraban la preexistente sociedad de gananciales, no se puede incardinar en la circunstancia del núm. 10 del artículo 890 C. de C., según la que se reputará quiebra fraudulenta cuando se hayan simulado por el quebrado enajenaciones de cualquier clase que éstas fuesen, ya que no se producen a virtud del alcance que ha de concedérsele a la preceptiva legal aquí invocada las "condiciones objetivas", para que el fraude se origine».

-Baró Casals ${ }^{28}$ ofrece la jurisprudencia siguiente:

a) Sobre el fondo de comercio, de fecha 20.06.1970: «Por incluir en el balance una partida en concepto de fondo de comercio, fondo que la sentencia de instancia declara inexistente e incluido con la única finalidad de ocultar contablemente las pérdidas habidas e inducir a error a los acreedores».

b) En relación con el capital social, de fecha de 14.06.1929: «Por incluir en el balance capital social que en realidad nunca se ingresó en la caja social, obteniendo mediante tal supuesto capital crédito para sus operaciones, originándose el estado de insolvencia determinante de la quiebra».

c) Respecto a los derechos de traspaso, de 28.03.1985: «... se ha probado la inclusión en el activo del balance de bienes supuestos, que el Tribunal Sentenciador concreta en el derecho de traspaso de un establecimiento comercial, con respecto al cual se había renunciado al mismo en el contrato de arrendamiento suscrito con la propiedad, y cuyo valor se fija en diez millones de pesetas, sin que quepa tampoco admitir la alegación que hace la recurrente de que, dado lo irrisorio del precio del arrendamiento, y la gran valía del inmueble arrendado, tal estado de cosas supone un valor en favor del arrendatario que debe reflejarse en su activo, ya que la renuncia expresa al derecho de traspaso convierte en ilusorio el valor del mismo, por lo que en modo alguno puede contabilizarse su existencia, debiendo, por consecuencia, decaer este segundo motivo».

28 Baró Casals, Antonio, op. cit., pp. 947-948. 
d) Sobre deudas supuestas, la misma de 28.03.1985: «por incluir créditos supuestos, pretendiéndose por el recurrente, con base de un motivo fundado en dicho ordinal primero, contradecir una afirmación fáctica como es la contenida en la resolución recurrida, de que no se ha probado la existencia del crédito a favor de..., sin que quepa alegar, como lo hace el recurrente, que no pueden imputarse a la entidad quebrada las consecuencias favorables o perjudiciales que se deriven de la defensa hecha por... de su crédito en la pieza cuarta, toda vez que, si bien la resolución recurrida, a mayor abundamiento, y como un simple "obiter dictum", hace constar que tampoco en dicha pieza cuarta, en la que por la citada entidad... no se impugnó adecuadamente la exclusión de su crédito, se acreditó su existencia, es lo cierto que aclara expresamente que, con antelación al mismo, no se ha logrado acreditar la realidad de su existencia, por todo lo cual procede la desestimación de este primer motivo».

García-Cruces ${ }^{29}$ señala: «De una atenta lectura de esta previsión del PLC lo primero que llama la atención es el alcance general e ilimitado de esta regla presuntiva. El tenor literal de la norma proyectada es extremadamente impreciso y una interpretación literal puede llevarnos a resultados absurdos. Todas las ideas anteriores nos han de obligar a buscar una interpretación más racional de la regla presuntiva, que se acomode a cuál pueda ser su finalidad y que evite resultados que no cabe amparar. En este sentido, me parece más acertado considerar que no todo acto de simulación ha de conllevar la aplicación de esta regla y la consiguiente calificación del concurso como culpable. En mi opinión, la aplicación de esta presunción debiera reducirse a los supuestos de simulación en que el acto llevado a cabo sea apto para conducir a tal resultado, pero, además, tenga una cierta relevancia, pues de lo contrario podría incurrirse en el absurdo». Sin embargo, la exposición de motivos de la Ley es clara: «La ley formula el criterio general de calificación del concurso como culpable y a continuación enuncia una serie de supuestos que, en todo caso, determinan esa calificación, por su intrínseca naturaleza...».

\subsubsection{PRESUnCiOnes}

El artículo 165 establece que se presume la existencia de dolo o culpa grave, salvo prueba en contrario, cuando el deudor o, en su caso,

${ }^{29}$ García-Cruces, José Antonio, op. cit., p. 273. 
sus representantes legales, administradores o liquidadores, incurran en los siguientes supuestos de hecho:

«1. Hubieran incumplido el deber de solicitar la declaración del concurso». Es decir, el deber de solicitar la declaración de concurso voluntario dentro del plazo de dos meses siguientes a la fecha en que hubiera conocido o debido conocer su insolvencia, que se presume cuando hayan transcurrido los plazos señalados en el art. 2.4.4. ${ }^{\mathrm{o} 30}$ (art. 5.1). Presunción de culpabilidad en la quiebra (art. 889.2. ${ }^{\circ}$ ), hasta la reforma del C. de C. en 1897, que explica detalladamente el auto, de fecha 29.12.1997, de la Audiencia Provincial de La Rioja.

Considera García-Cruces ${ }^{31}$ : «Este deber de instar el concurso, que obliga al deudor común a seguir tal proceder, obedece a un fundamento expreso y más que razonable, pues con su cumplimiento - concurso voluntario- se pueden anticipar las soluciones concursales y así evitar o minorar la producción de daños y el agravamiento de la deficitaria situación patrimonial, tal y como la práctica viene bien a enseñarnos».

«2. Hubieran incumplido el deber de colaboración con el Juez del concurso y la administración concursal, no les hubieran facilitado la información necesaria o conveniente para el interés del concurso o no hubiesen asistido, por sí o por medio de apoderado, a la Junta de acreedores». Es decir, por incumplimiento de los deberes de colaboración con los órganos concursales, establecidos en los artículos 21.1.3. ${ }^{\mathrm{o} 2}$, $42^{33}, 45^{34}$, así como del deber del concursado de asistir a la junta de acreedores para convenio, según dispone el art. 117.235. Es razonable la

${ }^{30} \mathrm{El}$ incumplimiento generalizado de obligaciones de alguna de las clases siguientes: las de pago de obligaciones tributarias exigibles durante los tres meses anteriores a la solicitud de concurso; las de pago de cuotas de la Seguridad Social y demás conceptos de recaudación conjunta durante el mismo período; las de pago de salarios e indemnizaciones y demás retribuciones derivadas de las relaciones de trabajo correspondientes a las tres últimas mensualidades.

31 García-Cruces, José Antonio, op. cit., p. 276.

32 En caso de concurso necesario, el requerimiento al deudor para que presente, en el plazo de diez días a contar desde la notificación del auto, los documentos enumerados en el artículo 6.

33 1. El deudor tiene el deber de comparecer personalmente ante el Juzgado de lo Mercantil y ante la administración concursal cuantas veces sea requerido y el de colaborar e informar en todo lo necesario o conveniente para el interés del concurso.

34 1. El deudor pondrá a disposición de la administración concursal los libros de llevanza obligatoria y cualesquiera otros libros, documentos y registros relativos a los aspectos patrimoniales de su actividad profesional o empresarial.

35 El concursado deberá asistir a la Junta de acreedores personalmente o hacerse representar por apoderado con facultades para negociar y aceptar convenios. 
incorporación de esta conducta omisiva del deudor y otros, como elemento que coadyuve a lograr un comportamiento activo y positivo del concursado, que supere la actual desidia del suspenso o quebrado, en general. El art. 890.3..$^{\circ}$ del C. de C. considera culpable al quebrado, si dejare de presentarse en los casos ordenados por la Ley.

«3. ${ }^{\circ}$ Si el deudor obligado legalmente a la llevanza de contabilidad, no hubiera formulado las cuentas anuales, no las hubiera sometido a auditoría, debiendo hacerlo, o, una vez aprobadas, no las hubiera depositado en el Registro Mercantil en alguno de los tres últimos ejercicios anteriores a la declaración de concurso». Es decir, el incumplimiento de los deberes establecidos en las leyes mercantiles, sobre contabilidad y auditoría $^{36}$, en particular, el título III del libro I del Código de comercio (arts. 34 y 41) y el capítulo VII del referido TRLSA (arts. 171, 203, 212 y 218).

\subsection{Cómplices}

El artículo 166 dispone que se consideran cómplices las personas que, con dolo o culpa grave, hubieran cooperado con el deudor o, si los tuviere, con sus representantes legales y, en caso de persona jurídica, con sus administradores o liquidadores, tanto de hecho como de derecho, o con sus apoderados generales, en la realización de cualquier acto que haya fundado la calificación del concurso como culpable.

\subsubsection{Derecho Concursal Vigente}

Soto Vázquez ${ }^{37}$ estudia la situación de los cómplices de las insolvencias fraudulentas, y anticipa que el tratamiento de la materia no es fácil, pues será preciso, en primer lugar, averiguar el sentido que se atribuye a la denominación de cómplice en las insolvencias fraudulentas, las secuelas civiles y mercantiles de incurrir en ese concepto, así como su posible relación con las consecuencias penales que ello lleva consigo; en segundo lugar, estudiar cada uno de los tipos recogidos en

${ }^{36}$ En sentido estricto, la ley (Código de Comercio de 1885, Ley de Auditoría de Cuentas de 1988 y Ley de Sociedades Anónimas de 1989) y, en sentido amplio, su desarrollo reglamentario (Plan General de Contabilidad de 1990, Normas para formulación de las cuentas anuales consolidadas de 1991, Reglamento de la Ley de Auditoría de Cuentas de 1990, Normas Técnicas de Auditoría de 1991, etc.).

37 Soto VÁzQuEZ, Rodolfo, Quiebras y concurso de acreedores. Las situaciones de insolvencia y la responsabilidad penal del deudor. Granada, Comares, 1994, pp. 319-337. 
la ley; y, en tercer lugar, determinar el régimen procesal aplicable a la declaración de complicidad fraudulenta, puesto que la Ley de Enjuiciamiento Civil guarda absoluto silencio al respecto.

Serán considerados cómplices de las quiebras fraudulentas (se intercalan comentarios de Soto Vázquez ${ }^{38}$ ), según el art. 893 del C. de C.:

1. ${ }^{\circ}$ «Los que auxilien el alzamiento de bienes del quebrado». Se resuelve sobre este caso en la STS de 19.12.1975, con fundamentos en el anterior CP. La inclusión de este motivo concreto - que no figuraba en el antiguo art. 1010 del C. de C. de 1829- no es sino consecuencia de haber incluido como caso de insolvencia fraudulenta la quinta clase de quiebra de este último cuerpo legal: «el alzamiento de bienes». En puridad de conceptos habría que distinguir en torno a la naturaleza de los actos de auxilio perpetrados, puesto que si se trata de actos de cooperación necesaria, desde el punto de vista de los conceptos penales generales al menos, habría de reputarse un supuesto de autoría y no de complicidad. Ello no obstante, no procede insistir demasiado en todas estas sutilezas, si tenemos en cuenta que, como se dijo anteriormente, el concepto de complicidad en las insolvencias fraudulentas es un concepto sustantivo y autónomo que no tiene que coincidir con el de complicidad penal. En los procesos concursales se persigue la dilucidación de las responsabilidades económicas del deudor insolvente como tema principal, y solamente después de que éstas hayan sido calificadas desde el punto de vista mercantil o civil se da paso a un enjuiciamiento penal de su conducta. La calificación de «cómplices fraudulentos» está hecha asimismo desde el punto de vista no penal, y creo que por eso mismo carece de relevancia que las conductas descritas bajo ese epígrafe puedan merecer otra conceptuación desde el punto de vista punitivo.

El quebrado podrá ser castigado, en el proceso penal correspondiente, con las penas previstas en los arts. 257 y 258 del CP.

2. ${ }^{\circ}$ "Los que, habiéndose confabulado con el quebrado para suponer créditos contra él o aumentar el valor de los que efectivamente tengan contra sus valores o bienes, sostengan esta suposición en el juicio de examen y calificación de los créditos o en cualquiera junta de acreedores de la quiebra». Examina este supuesto la STS de 23.01.1975, en relación con el anterior CP: «Para ser calificados de cómplices de quiebra fraudulenta, no basta el acuerdo, sino que es necesario que se sostenga por tales presuntos acreedores en la junta de examen y calificación de los créditos, o en cualquier otra junta de acreedores».

38 Soto VÁzquez, Rodolfo, op. cit., pp. 323-337. 
El quebrado podrá ser castigado ex art. 260 del CP, en el correspondiente proceso penal, cuando estos hechos sean causantes o agraven dolosamente la situación de crisis económica del deudor, en perjuicio de sus acreedores.

3. ${ }^{\circ}$ «Los que, para anteponerse en la graduación en perjuicio de otros acreedores y de acuerdo con el quebrado, alteraren la naturaleza o fecha del crédito, aun cuando esto se verifique antes de hacerse la declaración de quiebra».

4. ${ }^{\circ}$ «Los que deliberadamente, y después que el quebrado cesó en sus pagos, le auxiliaren para ocultar o sustraer alguna parte de sus bienes o créditos». La jurisprudencia ha destacado otro elemento necesario en la consideración de complicidad fraudulenta que, no por obvio, deja de ser importante el subrayar: el acuerdo entre deudor y cómplice tiene que ser susceptible de originar un perjuicio real a los acreedores del primero; de manera que si no es así, no se puede hablar de complicidad fraudulenta.

De nuevo, puede ponerse en relación con el tipo del art. 260 del CP.

$5 .^{\circ}$ «Los que, siendo tenedores de alguna pertenencia del quebrado al tiempo de hacerse notoria la declaración de quiebra por el Juez o Tribunal que de ello conozca, la entregaren a aquél, y no a los administradores legítimos de la masa, a menos que, siendo de nación o provincia diferente de la del domicilio del quebrado, prueben que en el pueblo de su residencia no se tenía noticia de la quiebra». Es fácilmente comprobable que, al referirse a la quiebra, este párrafo está sentando una auténtica presunción irrebatible de que incurren en complicidad fraudulenta los tenedores de pertenencias del insolvente que, teniendo su domicilio en la misma provincia, le hagan entrega de las mismas, en lugar de a los administradores; todo ello de acuerdo con lo que ordena el art. 1193 de la LEC, aplicable al concurso de acreedores, pero extensible a las quiebras por virtud del art. 1319, así como del art. 1057 del C. de C. de 1829.

6..$^{\circ}$ «Los que negaren a los administradores de la quiebra los efectos que de la pertenencia del quebrado existieren en su poder».

7. ${ }^{\circ}$ «os que, después de publicada la declaración de la quiebra, admitieren endosos del quebrado». Lógica tipificación, por demás manifestación específica de la prohibición de prestar cualquier auxilio encaminado a la ocultación de bienes del deudor, si se tiene en cuenta que la declaración de quiebra desapodera, a quien la sufre, de la habilitación para administrar sus bienes, según el art. 878 del C. de C. actual.

El quebrado que hiciese estos endosos, en favor de sus acreedores, con posposición del resto, puede incurrir en la sanción prevista en el art. 259 del CP. 
8. ${ }^{\circ}$ «Los acreedores legítimos que, en perjuicio y fraude de la masa, hicieren con el quebrado convenios particulares y secretos». En el caso de quiebra, los convenios, además de particulares, han de concertarse secretamente, con la salvedad de que es realmente poco verosímil que los conciertos particulares en perjuicio de tercero se estipulen de otra manera. Que el deudor insolvente no puede celebrar convenios particulares con sus acreedores, es algo que se deduce de la naturaleza misma del concurso o de la quiebra, así como de la misma inhabilitación que uno y otra llevan consigo para administrar por parte del insolvente (art. 1914 del CC y 878 del C. de C.), que con mayor motivo han de incapacitarle para concertar otros pactos que aquellos convenios que se estipulen regularmente en el curso del procedimiento de concurso o quiebra. De todas formas, el art. 899 del C. de C. es claramente expresivo al respecto, cuando ordena que los convenios entre los acreedores y el quebrado hayan de ser hechos en junta de acreedores debidamente constituida, sancionando con la nulidad los pactos particulares entre el quebrado y cualquiera de éstos, así como con la pérdida de los derechos en la quiebra al acreedor, y calificando de culpable al quebrado, siempre que no mereciese serlo como fraudulento. Es evidente, sin embargo, que esa sanción no implica por sí sola la declaración de complicidad fraudulenta a cargo de quien concertó los pactos particulares con el quebrado, en tanto no concurran las circunstancias que recoge este apartado.

9. ${ }^{\circ}$ «Los agentes mediadores que intervengan en operaciones de tráfico o giro que hiciere el comerciante declarado en quiebra». Debe tenerse en cuenta que resulta totalmente improcedente que la simple declaración — sin haber sido publicada siquiera — de la quiebra dé lugar a una imputación de complicidad fraudulenta, a no ser que se demuestre que el agente mediador conocía el estado de insolvencia del comerciante. Y también que, como se desprende de lo dispuesto en el art. $88^{39}$ del C. de C.,

39 (i) los Agentes de Cambio y Bolsa (cuyo Colegio fue disuelto y sus miembros integrados en el Cuerpo de Corredores de Comercio Colegiados, por virtud de la Disposición Adicional Segunda de la Ley del Mercado de Valores - Ley 24/1988);

(ii) los Corredores de Comercio Colegiados (cuyos miembros han quedado integrados junto a los Notarios en un Cuerpo único de Notarios, por virtud de la Disposición Adicional Vigesimocuarta de la Ley de Acompañamiento 55/1999, de 29 de diciembre, que estableció el régimen de dicha integración); y

(iii) los Corredores intérpretes de buques, hoy conocidos como Corredores Intérpretes Marítimos o simplemente como Corredores Marítimos, que se rigen por los artículos 112 a 115 del C.Com. y por su Reglamento, aprobado por Orden Ministerial de 30 de noviembre de 1933 (modificada por la de 5 de mayo de 1934). 
únicamente los agentes mediadores allí indicados se pueden considerar incluidos en el precepto.

Los cómplices de la quiebra serán condenados, civilmente, a perder cualquier derecho que tengan sobre la masa (normalmente su crédito) y a reintegrar los bienes y derechos sustraídos, con intereses e indemnización de daños y perjuicios (art. 894 del C. de C.). A los síndicos les compete exigir la responsabilidad, en su caso, previa determinación de aquéllos que hayan de ser considerados cómplices de las quiebras fraudulentas, en el ramo separado correspondiente seguido por el trámite de los incidentes. La calificación de quiebra fraudulenta y la declaración de complicidad pueden hacerse en un mismo procedimiento incidental, cuando sean conocidos con anterioridad a la apertura de la pieza de calificación los hechos constitutivos de complicidad, no habiendo norma procesal que lo impida, y sin que ello implique, por sí solo, indefensión para el tachado de cómplice, según se declara en la STS de 16.07.1991. Contrario sensu puede citarse la STS de 26.05.1972, que señala la posibilidad de que se ventile en incidente separado del de calificación la demanda de complicidad, cuando los hechos que la puedan producir sean conocidos con posterioridad a la sustanciación o resolución de la pieza de calificación.

Nada obstaculiza la pretensión de cualquier acreedor concursal a personarse y coadyuvar en este procedimiento de complicidad, a su exclusiva costa. Sobre la complicidad específica del art. 893 del C. de C., y sobre la culpabilidad genérica del Código Penal, se pronuncia la STS de 8.03.1979.

Ferrer Barriendos ${ }^{40}$ considera que en caso de complicidad, si quisiera sacarse alguna consecuencia lógica a la pieza, debería emplazarse al alegado cómplice contra el que se pidiera alguna responsabilidad civil. Ante problemas de efectiva indefensión se ha considerado por la jurisprudencia el carácter inquisitivo del expediente y su función reducida a la cuestión de la procedibilidad penal. Con tales premisas, no puede extrañar que las piezas de calificación hayan dejado de ser verdaderos procesos civiles con eficacia civil y que, incluso el Tribunal Supremo, en alguna ocasión, sugiera la remisión de las cuestiones civiles, vinculadas con este problema, al juzgado penal. Esta última postura parece la adecuada y, en el derecho proyectado, existe clara preocupación por garantizar la adecuada defensa de aquellas personas concretas contra las que se dirigen las pretensiones civiles, derivadas de la calificación de fraudulencia, porque de la sentencia se derivarán pronunciamientos de notable

40 Ferrer Barriendos, Agustín, op. cit., pp. 571-572. 
trascendencia civil. La perspectiva excesivamente «criminalista» y la referencia del art. 895 del Código de Comercio [la calificación de la quiebra, para exigir del deudor la responsabilidad criminal, se hará siempre en ramo separado...] ha lastrado un desarrollo razonable de las posibilidades de la pieza de calificación, que resulta más fácil de observar una vez la cuestión penal haya salido definitivamente de ella.

Resulta de interés el Fallo de la Sentencia del Juzgado de Primera Instancia n. ${ }^{\circ} 1$ de Gijón, de fecha 31.01.1997, y la Sentencia de la AP de Oviedo, de fecha 9.01.1998, que confirma el anterior: "FALLO: Que debo calificar y califico como fraudulenta la quiebra de la "Sociedad Promotora Urbanización el Rinconín, S.A.” y como cómplices de la quiebra a Dña. ..., D. ..., D. ..., "Edificaciones y Contratas Torremar, S.L.”, "Gómez Oviedo, S.L.” y "Banco Herrero, S.A.”, a quienes se condena a perder cualquier derecho que tengan a la masa de la quiebra y a reintegrar a la misma los bienes, derechos y acciones cuya sustracción ha dado lugar a su declaración de complicidad, con intereses e indemnización de daños y perjuicios; y una vez firme la presente resolución, procédase a la incoación de causa criminal para determinar la posible responsabilidad de este orden en que hayan podido incurrir la quebrada y los cómplices, deduciéndose testimonio del auto de declaración de quiebra, de la sentencia de fecha 31.05.1992 dictada en el incidente sobre revisión de la fecha de retroacción de la quiebra, del informe del señor comisario, junto con los documentos acompañados al mismo, exposición de los síndicos y censura del Ministerio Fiscal, así como de los escritos de oposición a la declaración de complicidad, la totalidad de los documentos aportados, salvo extractos bancarios y estados contables y de la presente sentencia; sin hacer expresa declaración de cuanto a las costas causadas en este incidente».

\subsubsection{EN EL NUEVO CONCURSO}

Pese a su marcado carácter penal, en general, puede definirse como cómplice la persona que acompaña o ayuda a otra en la comisión de un hecho reprobable, es decir, en el concurso, según el citado art. 166, quienes cooperen en la realización de cualquier acto determinado en los arts. 164 y 165, que fundamenta la declaración de culpabilidad.

Puntualiza García-Cruces ${ }^{41}:$ «... atendiendo al tenor literal del art. 165 PLC "hubieran cooperado con el deudor..." pudiera surgir la

41 García-Cruces, José Antonio, op. cit., pp. 283-284. 
duda de si este otro tipo de conductas _básicamente, aquellas reconducibles a la idea de encubrimiento- son susceptibles o no de quedar acogidas bajo la futura noción concursal de complicidad. Desde luego, la absoluta independencia de los órdenes penal y civil abogaría por una respuesta positiva, conforme a la cual no habría duda en subsumir bajo la noción de complicidad ex art. 165 PLC ese otro tipo de comportamientos y rehuir, de este modo, una interpretación del concepto de complicidad concursal basado en el significado técnico-penal del término. Pero, además, entiendo que la misma literalidad de la previsión que nos ocupa ha de llevarnos a igual resultado. En efecto, las conductas que no respondan al estricto significado penal de la complicidad y que encierren comportamientos propios del encubrimiento no repugnan al concepto concursal de complicidad, pues éste comprende la colaboración en los actos de causación de la insolvencia que permitieron la calificación del concurso como culpable, pero, también, en aquellos otros de agravamiento de tal estado y que permitieron igual calificación. Por ello, y atendiendo al significado material de esos otros actos de encubrimiento, no puede, desconocerse que con los mismos se agrava, mediante el ocultamiento, la realidad de la situación patrimonial y financiera del deudor común, razón que justifica la consideración del tercero encubridor como cómplice a los efectos previstos en el art. 165 PLC».

\subsection{Informe}

El artículo 169.1 establece que la administración concursal presentará al Juez un informe razonado y documentado sobre los hechos relevantes (artículos 164 y 165) para la calificación del concurso, con propuesta de resolución, y si la propuesta fuese como culpable expresará la identidad de las personas a las que deba afectar la calificación (el deudor o, si los tuviere, sus representantes legales y, en caso de persona jurídica, sus administradores o liquidadores, de derecho o de hecho) y la de las que hayan de ser consideradas cómplices, justificando la causa, así como la determinación de daños y perjuicios que, en su caso, se hayan causado por las personas anteriores. Dentro de los quince días siguientes al de expiración de los plazos para la personación de los interesados, la administración concursal presentará el mencionado informe. Insuficiente plazo, a mi juicio, dado el riguroso estudio que requiere y la trascendencia de este informe, con posibles consecuencias civiles e incluso penales para el deudor y terceros, como se deduce de los comentarios relativos a la sentencia de calificación. 
Cuando el deudor concursado fuese empresario mercantil, los administradores concursales deben comprobar el cumplimiento de la legislación contable, revisar la contabilidad y verificar las cuentas anuales o estados financieros intermedios, de cuya función auditora podrán valorar la conducta del deudor:

a) Si ha incumplido sustancialmente los deberes contables.

b) Si ha llevado doble contabilidad.

c) Si ha incurrido en irregularidad relevante en la llevanza contable.

d) Si alguno de los documentos aportados con la solicitud de concurso o presentados durante la tramitación del mismo adolecen de inexactitud grave.

e) Si la apertura de la liquidación ha sido acordada de oficio, por incumplimiento de convenio, con causa imputable al deudor.

f) Si ha ocultado, hecho desaparecer o transmitido a terceros bienes propios del deudor, con el efecto de haberse generado o agravado el estado de insolvencia, mediante dolo o culpa grave.

g) Si durante los dos años anteriores a la fecha de la declaración de concurso hubieran salido fraudulentamente de su patrimonio bienes o derechos. En particular, los administradores concursales deben investigar si se ha producido segregación de bienes del patrimonio del deudor, cuyo resultado es que el acreedor ha sido privado de las garantías de su crédito y que el deudor conserva su patrimonio, aunque ocultándolo.

h) Si antes de la fecha de la declaración de concurso ha realizado cualquier acto jurídico dirigido a simular una situación patrimonial ficticia.

i) Si ha incumplido el deber de solicitar la declaración del concurso.

j) Si ha incumplido el deber de colaboración con el Juez del concurso y la administración concursal.

k) Si no ha formulado las cuentas anuales.

1) Si no ha sometido a auditoría las cuentas anuales, debiendo hacerlo.

m) Si no ha depositado las cuentas anuales en el Registro Mercantil, en alguno de los tres últimos ejercicios anteriores a la declaración de concurso.

El concurso fortuito se define por exclusión, es decir, será fortuito el que no es culpable, por lo que se requiere el mismo esfuerzo investigador de la administración concursal, en aras de indagar y conocer si no se dan los supuestos de hecho enumerados precedentemente para la calificación de concurso culpable. Por omisión, los adminis- 
tradores concursales pueden incurrir en la responsabilidad prevista en el art. $36^{42}$.

El concurso culpable se anuda a la actuación dolosa o con culpa grave del deudor (arts. 164 y 165), que es causante de la incapacidad para cumplir regularmente sus obligaciones exigibles.

Del referido informe de la administración concursal se dará traslado al Ministerio Fiscal, para que emita dictamen sobre la calificación del concurso, en el plazo de diez días. Si el Ministerio Fiscal no emitiera dictamen, se entenderá conforme con la propuesta de calificación.

En los casos a que se refiere el apartado 2 del artículo $167^{43}$, el informe de la administración concursal y, en su caso, el dictamen del Ministerio Fiscal se limitarán a determinar las causas del incumplimiento, para dar respuesta a lo previsto en el art. 164.2.3. ${ }^{\circ}$, y si el concurso debe ser calificado como culpable.

\subsection{Tramitación de la sección de calificación}

Dispone el art. 170: «1. Si el informe de la administración concursal y el dictamen que, en su caso, hubiera emitido el Ministerio Fiscal coincidieran en calificar el concurso como fortuito, el juez, sin más trámites, ordenará el archivo de las actuaciones mediante auto, contra el que no cabrá recurso alguno».

El Juez deberá calificar el concurso como fortuito, por imperativo del mencionado art. 163.2, aunque el automatismo previsto le niegue toda posibilidad discrepante de los informes recibidos. Sin embargo, el precepto transcrito permite interpretar que no se calificará judicialmente el concurso, cuando los administradores concursales y, en su caso, el Ministerio Fiscal coincidan en su calificación como fortuito, ordenándose al Juez que archive las actuaciones, aunque de las alegaciones de los acreedores $\mathrm{u}$ otros interesados (art. 168 ${ }^{44}$ ) puedan deducirse indicios

42 1. Los administradores concursales y los auxiliares delegados responderán frente al deudor y frente a los acreedores de los daños y perjuicios causados a la masa por los actos y omisiones contrarios a la ley o realizados sin la debida diligencia.

${ }^{43}$ Cuando se hubiera formado la sección de calificación como consecuencia de la aprobación de un convenio con el contenido previsto en el número $1 .^{\circ}$ del apartado 1 del artículo 163 [quita superior a un tercio o espera superior a tres años] y, con posterioridad, éste resultare incumplido...

44 1. Dentro de los diez días siguientes a la última publicación que, conforme a lo establecido en esta Ley, se hubiere dado a la resolución judicial de aprobación del convenio o, en su caso, de apertura de la liquidación, cualquier acreedor o persona que acredite interés legítimo podrá personarse en la sección alegando por escrito cuanto considere relevante 
razonables de culpabilidad, no compartidos por la administración concursal ni por el Ministerio Fiscal. La exposición de motivos de la Ley indica: "Si el preceptivo informe de la administración concursal y el dictamen del Ministerio Fiscal coincidieran en la calificación del concurso como fortuito, se archivarán las actuaciones sin más trámites. En otro caso, la calificación como culpable se decidirá tras un contradictorio, en el que serán partes el Ministerio Fiscal, la administración concursal, el deudor y todas las personas que pudieran resultar afectadas por la calificación».

Cuando en alguno de los dos informes mencionados se hubiese calificado el concurso como culpable, el juez dará audiencia al deudor por plazo de diez días y ordenará emplazar a todas las personas que, según resulte de lo actuado, pudieran ser afectadas por la calificación del concurso (el deudor o, si los tuviere, sus representantes legales y, en caso de persona jurídica, sus administradores o liquidadores, de derecho o de hecho ¿se olvida de los apoderados generales, incluidos en el art. 166 sobre complicidad? o ¿pueden ser considerados administradores o liquidadores de hecho?) o declaradas cómplices (doy por supuesto que los apoderados generales pueden ser considerados cómplices), a fin de que, en plazo de cinco días, comparezcan en la sección si no lo hubieran hecho con anterioridad. No parece que sean emplazados los acreedores, ni tan siquiera aquéllos que formularon alegaciones iniciales. A quienes comparezcan en plazo se les dará vista del contenido de la sección para que, dentro de los diez días siguientes, aleguen cuanto convenga a su derecho. Si comparecieren con posterioridad al vencimiento del plazo, se los tendrá por parte sin retroceder el curso de las actuaciones. Si no comparecieren, serán declarados en rebeldía y seguirán su curso las actuaciones sin volver a citarlos.

Según el artículo 171, en el improbable caso de que no se formulara oposición a la declaración de culpabilidad, el juez dictará sentencia en el plazo de cinco días, y en el más probable escenario de que el deudor o alguno de los comparecidos formulasen oposición, el juez la sustanciará por los trámites del incidente concursal. De ser varias las oposiciones, se sustanciarán juntas en el mismo incidente (arts. 192 a 196). De nuevo, llamo la atención que se priva de legitimación a los acreedores concursales.

para la calificación del concurso como culpable. 2. En los casos a que se refiere el apartado 2 del artículo precedente, los interesados podrán personarse en la sección o en la pieza separada dentro del mismo plazo contado desde la última publicación que se hubiere dado a la resolución judicial de apertura de la liquidación, pero sus escritos se limitarán a determinar si el concurso debe ser calificado como culpable en razón de incumplimiento del convenio por causa imputable al concursado. 


\subsubsection{Sentencia de Calificación}

El artículo 172 dispone:

«1. La sentencia declarará el concurso como fortuito o como culpable. Si lo calificara como culpable, expresará la causa o causas en que se fundamente la calificación». Además de satisfacer la natural curiosidad de las partes personadas y de quienes se asomen la Registro público correspondiente, la mención de la causa o causas, en que se fundamente la declaración de concurso culpable, resulta obligada para explicar los pronunciamientos que siguen, en el apartado siguiente, y como antecedente, no vinculante, también, de posibles acciones penales, que se mencionan en el art. 163.2 ${ }^{45}$.

«2. La sentencia que califique el concurso como culpable contendrá, además, los siguientes pronunciamientos: $1 .^{\circ}$ La determinación de las personas afectadas por la calificación, así como, en su caso, la de las declaradas cómplices. Si alguna de las personas afectadas lo fuera como administrador o liquidador de hecho de la persona jurídica deudora, la sentencia deberá motivar la atribución de esa condición; $2^{\circ}{ }^{\circ}$ La inhabilitación de las personas afectadas por la calificación para administrar los bienes ajenos, durante un período de dos a quince años, así como para representar o administrar a cualquier persona, durante el mismo período, atendiendo, en todo caso, a la gravedad de los hechos y a la entidad de perjuicio; $3 .^{\circ}$ La pérdida de cualquier derecho que las personas afectadas por la calificación o declaradas cómplices tuvieran como acreedores concursales o de la masa y la condena a devolver los bienes o derechos que hubieran obtenido indebidamente del patrimonio del deudor o hubiesen recibido de la masa activa, así como a indemnizar los daños y perjuicios causados». En primer lugar, la Sentencia señalará la identidad de los afectados (el deudor o, si los tuviere, sus representantes legales y, en caso de persona jurídica, sus administradores o liquidadores, de derecho o de hecho ¿se olvida de los apoderados generales, incluidos en el art. 166 sobre complicidad?) y de los declarados cómplices, indispensable para acordar su inhabilitación y para privarles de los derechos de crédito que tuvieren reconocidos en el concurso, así como para condenarles a devolver lo que hubieren obtenido indebidamente del deudor o del concurso y a indemnizar los daños y perjuicios causados.

45 El concurso se calificará como fortuito o como culpable. La calificación no vinculará a los jueces y tribunales del orden jurisdiccional penal que, en su caso, entiendan de actuaciones del deudor que pudieran ser constitutivas de delito. 
El pronunciamiento de la Sentencia calificadora del concurso sobre este último inciso, dedicado a daños y perjuicios, trae causa en la estimación hecha por los administradores concursales en su informe, según el art. 169.1 in fine $e^{46}$.

«3. Si la Sección de calificación hubiera sido formada o reabierta como consecuencia de la apertura de la fase de liquidación, la sentencia podrá, además, condenar a los administradores o liquidadores, de derecho o de hecho, de la persona jurídica, cuyo concurso se califique como culpable, y a quienes hubieren tenido esta condición, dentro de los dos años anteriores a la fecha de la declaración de concurso, a pagar a los acreedores concursales, total o parcialmente, el importe que de sus créditos no perciban en la liquidación de la masa activa». Concordante con lo dispuesto en el art. $48.3^{47}$, sobre medidas cautelares, aunque llama la atención (reitero la cuestión sobre los apoderados generales) que la sentencia de calificación pueda condenar a quienes hayan sido administradores o liquidadores de derecho o de hecho, dentro de los dos años anteriores a la fecha de la declaración de concurso ¿sin ser oídos?

«4. Quienes hubieran sido parte en la sección de calificación podrán interponer contra la sentencia recurso de apelación». Reitero que se impide la posibilidad de que un acreedor concursal cualquiera pueda recurrir la Sentencia, así como, al parecer, a los administradores o liquidadores, de derecho o de hecho, que lo hayan sido dentro de los dos años anteriores a la declaración de concurso, pues no he encontrado disposición alguna en la que se les considere parte.

De la exposición de motivos de la nueva Ley, conviene acotar: «Los efectos de la calificación se limitan a la esfera civil, sin trascender a la penal ni constituir condición de prejudicialidad para la persecución de las conductas que pudieran ser constitutivas de delitos. La ley mantiene la neta separación de ilícitos civiles y penales en esta materia».

46 ...determinación de los daños y perjuicios que, en su caso, se hayan causado por las personas anteriores.

${ }^{47}$ Desde la declaración de concurso de persona jurídica, el juez del concurso, de oficio o a solicitud razonada de la administración concursal, podrá ordenar el embargo de bienes y derechos de sus administradores o liquidadores de derecho o de hecho, y de quienes hubieran tenido esta condición dentro de los dos años anteriores a la fecha de aquella declaración, cuando de lo actuado resulte fundada la posibilidad de que el concurso se califique como culpable y de que la masa activa sea insuficiente para satisfacer todas las deudas. El embargo se acordará por la cuantía que el juez estime bastante y podrá ser sustituida, a solicitud del interesado, por aval de entidad de crédito. 


\subsubsection{SUSTITUCIÓN DE LOS INHABILITADOS}

El art. 173 dispone: «Los administradores y los liquidadores de la persona jurídica concursada que sean inhabilitados cesarán en sus cargos. Si el cese impidiese el funcionamiento del órgano de administración o liquidación, la administración concursal convocará junta o asamblea de socios para el nombramiento de quienes hayan de cubrir las vacantes de los inhabilitados». Parece deducirse que no todos los administradores o liquidadores de la entidad concursada pueden ser afectados por la calificación de concurso culpable, lo cual parece razonable, y que sólo las personas afectadas quedarán inhabilitadas y cesarán en sus cargos, cuando sean administradores o liquidadores sociales. No se contempla la posibilidad, más que probable, de que nadie se preste a aceptar el cargo para cubrir las vacantes de los inhabilitados.

\section{Recapitulación}

La calificación del concurso en la nueva Ley, objeto de anteriores comentarios, presenta notables cambios respecto de la vigente legislación concursal, que trataré de resumir.

Primero.- Sólo tendrá lugar la apertura de la sección sexta de calificación: a) Cuando en el convenio aprobado se establezca una quita superior a un tercio o una espera superior a tres años, para todos los acreedores o para las de una o varias clases; y, b) En todos los supuestos de apertura de la fase de liquidación.

Segundo.- Solamente dos clases de calificación concursal: fortuita o culpable.

Tercero.-La conducta del deudor, que puede determinar la calificación de concurso culpable, recuerda el tipo de las insolvencias punibles ex art. $260 \mathrm{CP}:$ : 1 . El que fuere declarado en quiebra, concurso o suspensión de pagos será castigado..., cuando la situación de crisis económica o la insolvencia sea causada o agravada dolosamente por el deudor o persona que actúe en su nombre».

Cuarto.-La culpabilidad se presume:

A) Iuris et de iure: a) Por incumplimientos sustanciales contables; b) Por falsedad documental, que algo tiene que ver con el tipo del art. $261 \mathrm{CP}$ : «El que en procedimiento de quiebra, concurso o expediente de suspensión de pagos presentare, a sabiendas, datos falsos relativos al estado contable, con el fin de lograr 
indebidamente la declaración de aquéllos...»; c) Por incumplimiento de convenio, debido a causa imputable al concursado; d) Por alzamiento de bienes, también relacionado con los arts. 257 y $258 \mathrm{CP}$; etc.

B) Iuris tantum: a) Incumplimiento del deber de solicitar la declaración de concurso; b) Incumplimiento del deber de colaboración con los órganos concursales; c) Incumplimientos formales contables.

Quinto.-Sobre cómplices, llamo la atención del riesgo para asesores, auditores y otros profesionales, que hubiesen cooperado en el deudor en incumplimientos contables, falsedades documentales o simulaciones patrimoniales.

Sexto.-El informe de los administradores concursales sobre la calificación del concurso reviste importancia capital y requiere competencia pericial, sujeta a responsabilidades personales.

Séptimo.-La calificación culpable del concurso anuda consecuencias indeseables para las personas afectadas (deudor, representantes legales, administradores o liquidadores, de derecho o de hecho): a) inhabilitación; b) pérdida de sus derechos de crédito en el concurso; c) devolución de bienes o derechos; d) indemnización de daños o perjuicios. También, para los declarados cómplices: b), c) y d) precedentes.

Octavo.-Si la calificación de culpable tiene lugar como consecuencia de la apertura de la liquidación, la sentencia podrá condenar a las personas afectadas de la entidad concursada, y a quienes hubieran sido sus administradores o liquidadores, de derecho o de hecho, dentro de los dos años anteriores a la declaración de concurso, a pagar a los acreedores concursales, total o parcialmente, el importe que de sus créditos no perciban en la liquidación de masa activa. Pues bien, no parece que sean personas afectadas estos administradores y liquidadores anteriores ¿cómo pueden ser condenados, sin ser oídos?

Noveno.-La calificación de culpable conlleva la inhabilitación temporal de las personas afectadas para la administración de bienes ajenos y, en su caso, el cese como administradores o liquidadores de la persona jurídica concursada, que deberán ser sustituidos, si su cese impidiese el funcionamiento del órgano de administración o liquidación.

Décimo.-A modo de conclusión, las consecuencias personales y patrimoniales (represivas) que se derivan de la calificación de culpabilidad, para el deudor, en el nuevo concurso, sugieren la siguiente reflexión o recomendación: Quienes se encuentren en estado de insolven- 
cia o la prevean inminente, ahora y hasta el 1.09.2004, fecha de entrada en vigor de esta Ley, deben solicitar la declaración de suspensión de pagos o quiebra, según convenga, pues se acepta ${ }^{48}$ que la Ley de 26 de julio de 1922 permite la tramitación de la suspensión de pagos, a instancia del empresario que no posee bienes suficientes para pagar todas sus deudas, y se interpreta ${ }^{49}$ que este proceso se ha convertido en una quiebra abreviada, por la abrogación de los requisitos establecidos en los arts. 870 a 872 del C. de C.

48 Circular 1/1995 de la Fiscalía General del Estado.

49 Torres De Cruells, Joaquín, op. cit., p. 229. Garrigues DíAZ-CABAÑETE, Joaquín, «En torno a la reforma del derecho mercantil», en Jornadas sobre la reforma de la legislación mercantil, Madrid, Civitas, 1979, p. 390. Rojo FernándeZ-Río, Angel, BELTRÁN SÁncheZ, Emilio M. y CAMPuZANo Laguillo, Ana Belén, Legislación y jurisprudencia concursales, Pamplona, Aranzadi, 1997, p. 108. Ramos MÉndeZ, Francisco, Derecho procesal civil, Barcelona, Bosch, 1980, p. 1117. MENÉNDEZ, Aurelio, «Breves reflexiones sobre la reforma del Derecho concursal», en Homenaje a José María Chico y Ortiz, Madrid, Colegio de Registradores de la Propiedad y Mercantiles de España/ Marcial Pons, 1995, p. 1316. GonzÁlez de Echávarri, José M. a y Miguel Romero, Mauro, Comentarios a la Ley de Suspensión de Pagos, Valladolid, Emilio Zapatero (imp.), p. 153; TorRes DE CruELLS, Joaquín, op. cit., p. 83; SAGRera Tizón, José M.a op. cit., vol. I, pp. 164-166; Bisbal MénDEZ, Joaquín, La empresa en crisis y el derecho de quiebras, Bolonia, Publicaciones del Real Colegio de España, 1986, pp. 150-151; Mascarell NAVArro, M. ${ }^{a}$ José, Aspectos procesales de la Ley de suspensión de pagos, Granada, Comares, 1994, pp. 12-13. MENÉNDEZ, Aurelio, «Sobre la reforma del Derecho concursal y el apoyo de los estudios económicos», Revista del Consejo General de la Abogacía Española, septiembre 1994, n. ${ }^{\circ}$, pp. 6-7. Guasch Martorell, Rafael, «Aproximación crítica a la protección de la integridad del patrimonio concursal en la Ley de suspensión de pagos», Revista de Derecho Mercantil, abril-junio 1995 (núm. 216), p. 520. 